\title{
Extraction and Physico-Chemical Characterization of Pectins from Sugar Beet Pulp
}

\author{
Runcang SuN ${ }^{\dagger}$ and Sara Hughes \\ The BioComposites Centre, University of Wales, Bangor, Gwynedd, LL57 2UW, U.K.
}

(Received March 4, 1998)

\begin{abstract}
Sugar beet pulb (SBP) pectins were isolated from the proteolysis hydrolysates or extracted by $\mathrm{HCl}(\mathrm{pH} 1.5$, $85^{\circ} \mathrm{C}$ for $1-6 \mathrm{~h}$ and $\mathrm{pH} 1.5,4 \mathrm{~h}$ at $40-90^{\circ} \mathrm{C}$ ), ethylenediamine tetraacetate (EDTA, $0.2 \%, \mathrm{pH} 3.3,85^{\circ} \mathrm{C}, 1,4 \mathrm{~h}$ ), ammonium oxalate (AO, 0.2\%, pH 3.3, $4 \mathrm{~h}$ ), and sodium hexametaphosphate (SHP, 0.2\%, pH 3.3, $4 \mathrm{~h}$ ). An optimal $\mathrm{HCl}$ extraction (pH $1.5,85^{\circ} \mathrm{C}, 4 \mathrm{~h}$ ) yielded $16.94 \%$ pectin from the dewaxed and protein-free SBP. The $\mathrm{HCl}$ extracted pectin contained $84.61 \%$ galacturonic acid and low ash, $2.69 \%$. The degree of methylation was over $60 \%$ in all the pectin samples, indicating that the sugar beet pectin is a high methoxy pectin. The degree of acetylation ranged between $10.80 \%$ and $14.78 \%$, resulting in poor gelling capacity of the pectins. The pectins also contained $7.21 \%$ to $10.73 \%$ neutral sugars, which were mainly arabinose and galactose. The molecular-average weights ranged between around 60000 and $90000 \mathrm{Da}$. It was found that lignin in SBP cell walls is tightly associated with pectin. Besides the esterified ferulic acid, seven other phenolic monomers, principally vanillin and $p$-hydroxybenzoic acid, were initially identified in the alkaline nitrobenzene oxidation of bound lignin in the isolated pectin samples.
\end{abstract}

KEY WORDS Sugar Beet Pulp / Pectin / Galacturonic Acid / Sugars / Molecular Weight / Extraction / Ferulic Acid / Phenolics / Lignin /

Sugar beet pulp (SBP) is a by-product of the sugar refining industry, and it is used as animal feed at relatively low price. It consists mainly of polysaccharides (approximately $70 \%$ of the dry matter), of which pectin $(25 \%)$, arabinan $(21 \%)$, and cellulose $(24 \%)$ prevail. It is therefore a potentially rich source. ${ }^{1,2}$ The pectins of sugar beet are complex heteropolysaccharides containing galacturonic acid, rhamnose, arabinose, and galactose as the major sugar constituents. They are characterized by a backbone of $\alpha-(1 \rightarrow 4)$-linked galacturonic acid residues, forming long smooth regions which may be interrupted by hairy regions, consisting of a $1: 1$ ratio of galacturonic acid and $(1 \rightarrow 2)$-linked rhamnose residues in the backbone, and a high degree of substitution of the rhamnogalacturonan. Some rhamnose residues carry side chains, consisting mainly of $(1 \rightarrow 5)$-linked $\alpha$-arabinans with branches attached to position $3,(1 \rightarrow 4)$-linked $\beta$-galactans of low polymerization degree, and highly branched $(1 \rightarrow 3,6)$-linked galactans. ${ }^{3,4}$ Beet pectins, however, differ from pectins isolated from apple or citrus by their high rhamnose content, ${ }^{5}$ by the presence of acetyl groups linked to the $\alpha$-D-galacturonic acid and by the presence of ferulic acid; which is associated almost exclusively with the pectic side chains and is found ester-linked to either the C-2 of arabinofurance or to the C-6 of galactopyranose residue. ${ }^{6,7}$ Further studies suggest that the ferulic acid is distributed about equally between the arabinan and galactan moieties of SBP. ${ }^{4,8}$ Due to the low molecular weight and the presence of acetyl groups, the pectins of SBP have poor gelling properties and low viscosity which limit its use as a gelling or thickening agent. ${ }^{1}$ Interestingly, the isolated feruloylated pectins from SBP can gel by cross-linking through their feruloyl groups in the presence of a mixture of peroxidase/hydrogen peroxide, or of ammonium persulfate, ${ }^{9}$ which indicates a new method of gelation and consequently commercial use of SBP pectins.

\footnotetext{
† To whom correspondence should be addressed.
}

The aim of this study was to optimize the extraction procedure for beet pulp pectins with a maximal yield, and to study the physico-chemical characteristics of the isolated pectic polysaccharides. Special attention is also paid to their lignin content and phenolic monomer composition as well as their ferulic acid content.

\section{MATERIALS AND METHODS}

\section{Materials}

SBP was obtained from the Danisco Sugar Development Centre, Denmark. The dried SBP was ground in a Christie Laboratory Mill to pass a 60 mesh size screen and stored at $5^{\circ} \mathrm{C}$ until use. Protease (EC 3.4.24.31) and citrus pectin were obtained from the Sigma Chemical Co., St. Louis, Mo., U.S.A. Crude lipids were Soxhlet extracted using chloroform-methanol $(2: 1, \mathrm{v} / \mathrm{v})$ for $6 \mathrm{~h}$. Proteolysis was performed by addition of protease into $0.1 \mathrm{M}$ sodium phosphate buffer $(\mathrm{pH} 7.5$ ) containing defatted SBP at $37^{\circ} \mathrm{C}$ for $2 \mathrm{~h}$. The water solubilized pectic polysaccharides were isolated from the hydrolysates of proteolysis by precipitation with 4 vols ethanol. The dewaxed and protein-free SBP was used for further extraction of the pectins.

\section{Extraction of Pectins}

The pectins were extracted from the protein-free SBP by four different extraction procedures: (1) acid $(\mathrm{HCl})$ extraction: the pulps $(7.26 \mathrm{~g})$ were dispersed in $\mathrm{pH} 1.5$ $\mathrm{HCl}$ solution $(900 \mathrm{~mL})$. The mixtures were extracted at $85^{\circ} \mathrm{C}$ under stirring for $1,2,3,4$, and $6 \mathrm{~h}$, respectively, and for $4 \mathrm{~h}$ at $40,60,75,85$, and $90^{\circ} \mathrm{C}$, respectively. (2) disodium ethylenediamine tetraacetate acid (EDTA) extraction: the protein-free SBP $(7.26 \mathrm{~g})$ was mixed with $0.2 \%(\mathrm{w} / \mathrm{v})$ of EDTA solution $(900 \mathrm{~mL})$, adjusted to $\mathrm{pH}$ 3.3 with concentrated $\mathrm{HCl}$ and extracted at $85^{\circ} \mathrm{C}$ for 1 and $4 \mathrm{~h}$, respectively. (3) ammonium oxalate (AO) extraction, and (4) sodium hexametaphosphate (SHP) extraction. In the latter two cases, the samples $(7.26 \mathrm{~g})$ 


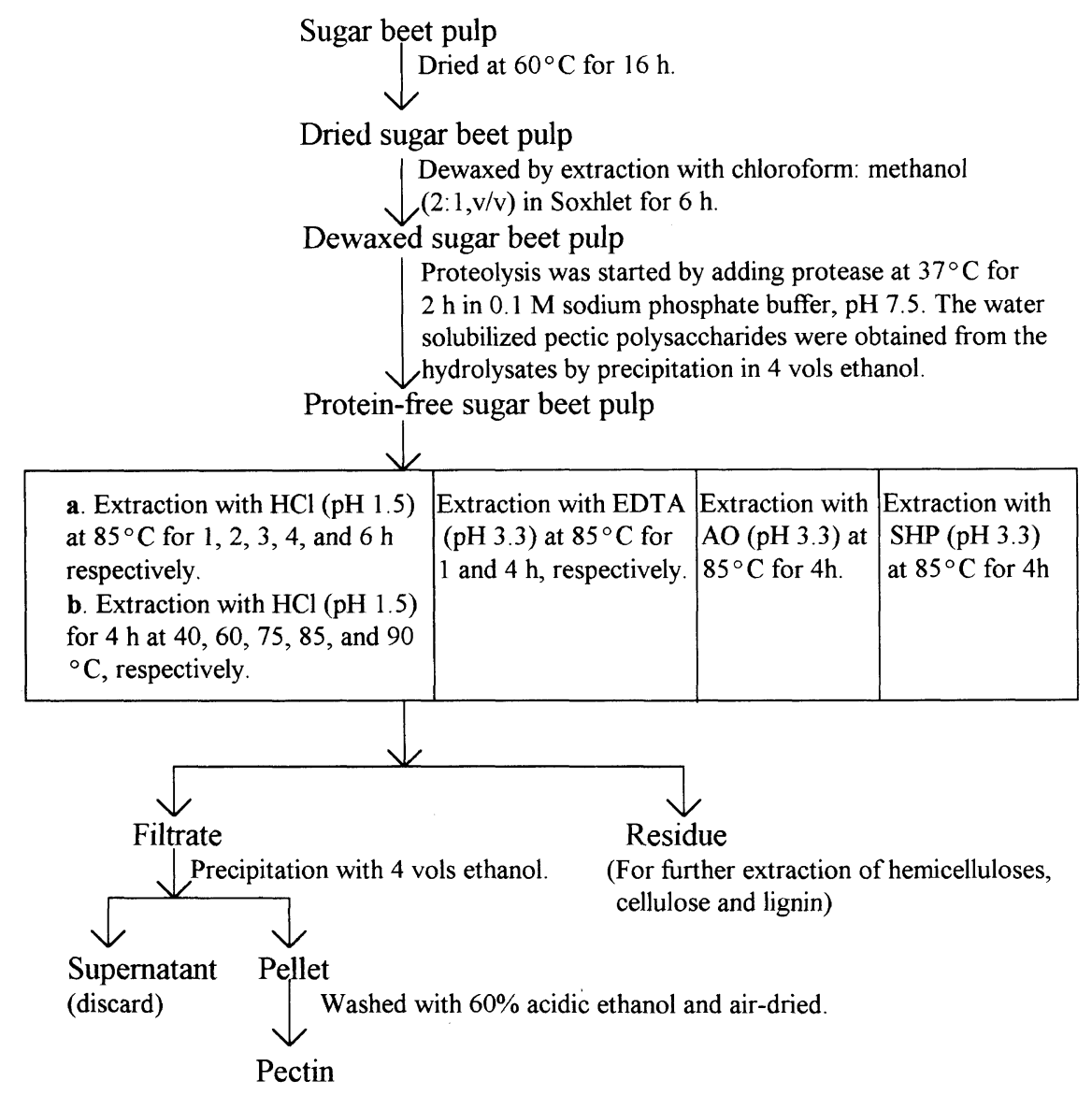

Figure 1. Scheme for extraction and isolation of pectins from sugar beet pulp.

were extracted in $0.2 \% \mathrm{AO}$ and $0.2 \%$ SHP solution $(900 \mathrm{~mL})$, respectively and adjusted with $20 \% \mathrm{HCl}$ to $\mathrm{pH} \mathrm{3.3,} \mathrm{at} 85^{\circ} \mathrm{C}$ for $4 \mathrm{~h}$. The scheme for extraction and isolation of the pectins from dewaxed and protein-free SBP is shown in Figure 1. After extraction, the filtrates were adjusted to $\mathrm{pH} 4.0$ with $1 \mathrm{M} \mathrm{NaOH}$. The pectins were recovered by precipitation of the filtrates in 4 vols of ethanol, washed with $60 \%$ acidic ethanol, and airdried.

\section{Characterization of Pectins}

Neutral sugar composition in isolated pectins was determined as alditol acetates. ${ }^{10}$ The anhydrogalacturonic acid content of the pectins was estimated by a colorimetric procedure using 3-phenylphenol color reagent according to the procedure outlined by Blumenkrantz and Asboe-Hansen ${ }^{11}$ with the modification of Wedig and co-workers. ${ }^{12}$ Methyl ester content was determined according to the method described by Wood and Siddiqui. ${ }^{13}$ Acetic acid content was estimated using the transesterification method outlined by Browning. ${ }^{14}$

Viscosity was measured using a Brookfield SynchroLectric Viscometer (Model LV). A citrus pectin was used as a reference. Pectin samples $(1 \%, \mathrm{w} / \mathrm{v})$ were prepared in $0.1 \mathrm{M}$ sodium phosphate buffer, $\mathrm{pH} 7.0$ and allowed to hydrate at $4^{\circ} \mathrm{C}$ for $16 \mathrm{~h}^{1,15}$ Viscosity was then estimated (cps) at $25^{\circ} \mathrm{C}$.

Optical rotation was determined on a polarimeter (Perkin Elmer, type 108) according to the methods described by Phatak et al. ${ }^{1}$ and McCready et al. ${ }^{16}$ Pectin samples $(1.0 \%, \mathrm{w} / \mathrm{v})$ were prepared in double distilled water, and solutions were centrifuged before measurement of optical rotation. A citrus pectin was used as a reference.

Gelling property of the pectins was tested according to the procedures of Phatak et al. ${ }^{1}$ and Chang and Miyamoto. ${ }^{17}$ Pectin samples were prepared in distilled water at a concentration of $1.0 \%(\mathrm{w} / \mathrm{v})$.

Ferulic acid content was measured by saponification with $4 \mathrm{M} \mathrm{NaOH}$ at $170^{\circ} \mathrm{C}$ for $2 \mathrm{~h}$. The other phenolic monomers from the associated lignins in the pectin samples were obtained by alkaline nitrobenzene oxidation at $170^{\circ} \mathrm{C}$ for $3 \mathrm{~h}$, and determined by HPLC. The weight-average molecular weights of the pectins were determined by gel permeation chromatography. ${ }^{18-20}$ FT-IR spectra were obtained on an FT-IR spectrophotometer (Nicolet, 750) using a $\mathrm{KBr}$ disc containing $1 \%$ finely ground samples.

\section{RESULTS AND DISCUSSION}

\section{Yield and Chemical Composition}

Treatment of SBP with protease at $37^{\circ} \mathrm{C}$ for $2 \mathrm{~h}$ in $0.1 \mathrm{M}$ sodium phosphate buffer $(\mathrm{pH} 7.5)$ produced water-soluble pectin, $15.20 \%$. The extraction of proteinfree SBP with $\mathrm{HCl}$, EDTA, AO, and SHP yielded $11.62 \%$ $(\mathrm{HCl}, 1 \mathrm{~h}), 16.94 \%(\mathrm{HCl}, 4 \mathrm{~h}), 6.70 \%$ (EDTA, $1 \mathrm{~h})$, $14.12 \%$ (EDTA, $4 \mathrm{~h}$ ), $10.90 \%(\mathrm{AO}, 4 \mathrm{~h}$ ), and $14.81 \%$ (SHP, $4 \mathrm{~h}$ ), respectively (Table I). The pectin samples obtained by these extraction procedures were assayed for determination of the physico-chemical properties. The highest yield among the four procedures was obtained 
when the SBP was extracted with $\mathrm{HCl}(\mathrm{pH} 1.5)$ at $85^{\circ} \mathrm{C}$ for $4 \mathrm{~h}$. Increase of extraction time from 1 to $6 \mathrm{~h}$ at $85^{\circ} \mathrm{C}$ with $\mathrm{HCl}$ solution $(\mathrm{pH} 1.5)$ resulted in increase of pectin yield from $11.62 \%$ to $18.73 \%$ (Figure 2), indicating that extension of the extraction period favored pectin extraction. The same trend appeared during the extractions at the various temperatures. As shown in Figure 3, the pectin yields increased significantly from $6.21 \%$ to $12.01 \%$, and to $16.94 \%$ during the extraction with $\mathrm{HCl}$ $(\mathrm{pH} 1.5)$ for $4 \mathrm{~h}$ as temperature increased at $60^{\circ} \mathrm{C}, 75^{\circ} \mathrm{C}$, and $85^{\circ} \mathrm{C}$, respectively. Further increase of temperature from $85^{\circ} \mathrm{C}$ to $90^{\circ} \mathrm{C}$ brought about slight growth of pectin yield from $16.92 \%$ to $17.50 \%$. The current data indicated that the yield of pectin increased rapidly with increasing

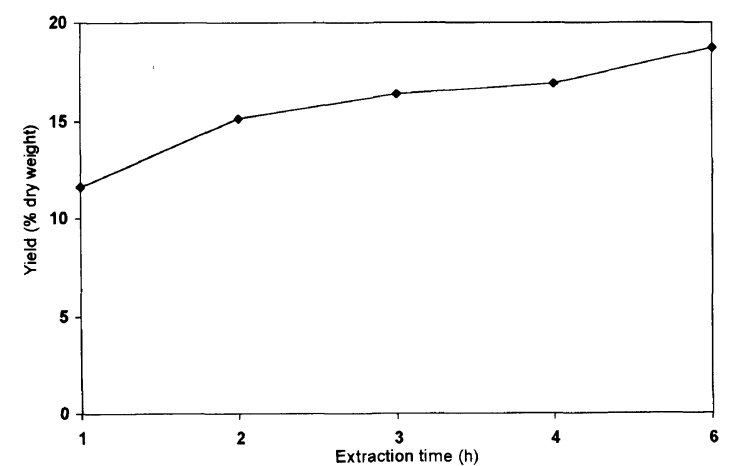

Figure 2. The effect of extraction time on the yield of pectin extracted with $\mathrm{HCl}$ at $\mathrm{pH} 1.5$ and $85^{\circ} \mathrm{C}$.

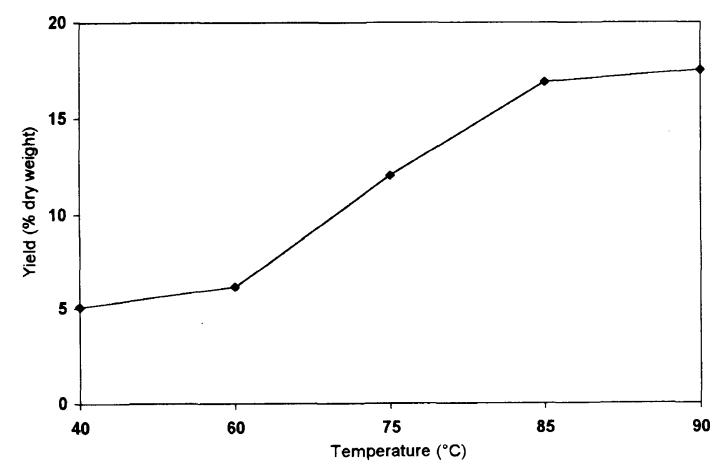

Figure 3. The effect of extraction temperature on the yield of pectin extracted with $\mathrm{HCl}$ at $\mathrm{pH} 1.5$ for $4 \mathrm{~h}$. temperature between $60^{\circ} \mathrm{C}$ and $85^{\circ} \mathrm{C}$, and then remained constant. The results obtained did not agree with Phatak and co-workers' study, ${ }^{1}$ which indicated that the pectin yields from various extractions at $90^{\circ} \mathrm{C}$ were lower than those at $80^{\circ} \mathrm{C}$, and therefore, they stated some degradation of pectin occurred at $90^{\circ} \mathrm{C}$. Further study is to be done in order to explain these different phenomena.

The higher galacturonic acid and the lower ash contents of pectin are the two criteria for its purity. ${ }^{21}$ It is evident from Table I that the purest pectin with the highest yield was produced by $\mathrm{HCl}(\mathrm{pH} \mathrm{1.5,4h)}$ extraction; in which the pectin fraction contained $84.61 \%$ galacturonic acid and less than $3 \%$ ash. The anhydrogalacturonic acid contents $(81.08-84.61 \%)$ of the pectins obtained by $\mathrm{HCl}$ and $\mathrm{AO}$ extraction were similar to those present in commercial apple pectin $(80 \%)$, whereas the anhydrogalacturonic acid contents of SHP, EDTA, and water extracted pectins were found to be lower, $44.94 \%$, $62.35-68.40 \%$, and $67.66 \%$, respectively. In contrast with the anhydrogalacturonic acid content, the pectins extracted with SHP, EDTA, and water contained much higher amounts of ash. Since the carboxyl groups of the galacturonic acid units in pectin molecules are partially neutralized with cations, ${ }^{22}$ the higher ash content of the pectins isolated by SHP and EDTA extractions may be attributed to the complexing property of EDTA or SHP with metal ions. ${ }^{21}$ Phatak et al. ${ }^{1}$ also reported that the ash content in pectin isolated by EDTA was higher than those isolated by $\mathrm{HCl}$ and $\mathrm{AO}$ extractions.

The degree of methylation in all the pectin samples was found to be over $60 \%$, indicating that the pectins obtained from SBP are high methoxy pectins. The degree of acetylation showed slight changes $(10.80-14.78 \%)$ in the isolated pectin samples obtained during the various extraction procedures. However, Phatak and coworkers ${ }^{1}$ indicated that the degree of acetylation varied significantly depending upon extraction procedures. They reported that the degree of acetylation in pectin isolated by $\mathrm{HCl}$ was only $4.26 \%$, whereas it increased to $19.03 \%$ and $25.22 \%$, respectively in the pectin samples extracted by EDTA and AO. Michel et al. ${ }^{23}$ also showed that the sugar beet pectin contained 21 to 25 acetyl groups per 100 molecules of anhydrogalacturonic acid. These different degrees of acetylation were probably due to the nature of the samples and the various extraction

Table I. The chemical composition of pectins extracted by different procedures

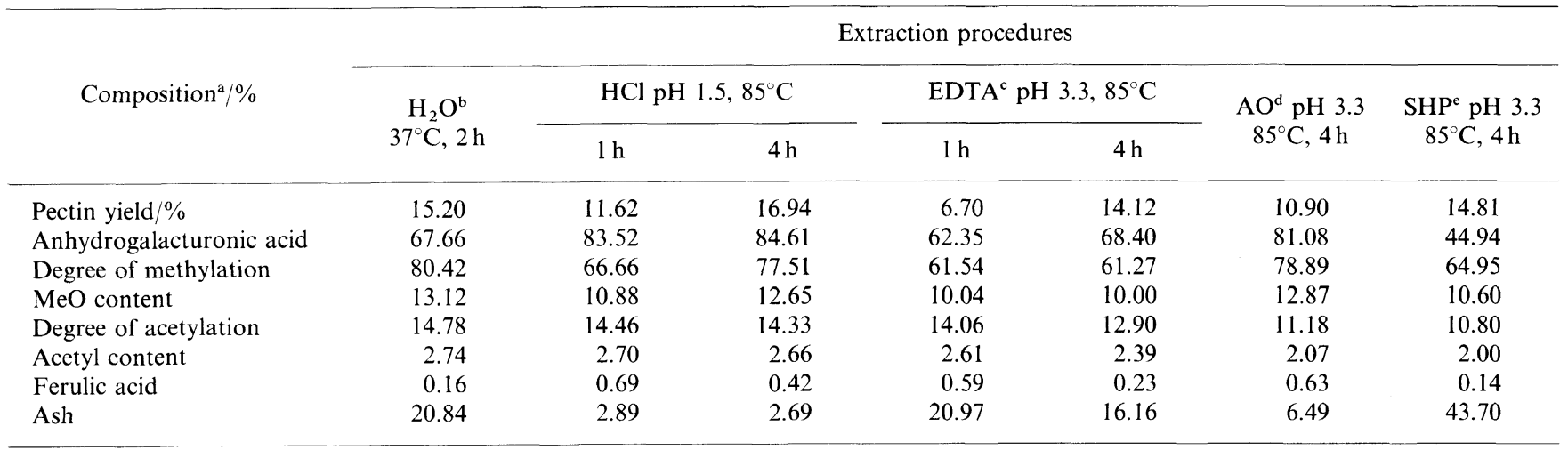

${ }^{\mathrm{a}}$ Data are expressed on a dry basis of SBP for pectin yield and of pectin for others, and represent the mean of duplicate runs. ${ }^{\mathrm{b}}$ Indication of the pectin fraction solubilized during the proteolysis $\left(0.1 \mathrm{M}\right.$ sodium phosphate buffer, $\left.\mathrm{pH} 7.5,37^{\circ} \mathrm{C}, 2 \mathrm{~h}\right)$. ${ }^{\mathrm{c}} \mathrm{Abbreviation}$ for ethylenediamine tetraacetate. ${ }^{d}$ Abbreviation for ammonium oxalate. ${ }^{\mathrm{e}}$ Abbreviation for sodium hexametaphosphate. 
Table II. The content ( $\%$ dry pectin, w/w) of neutral sugars in pectin fractions extracted from sugar beet pulp

\begin{tabular}{|c|c|c|c|c|c|c|c|}
\hline \multirow{3}{*}{ Neutral sugars ${ }^{a}$} & \multicolumn{7}{|c|}{ Extraction procedures } \\
\hline & \multirow{2}{*}{$\begin{array}{c}\mathrm{H}_{2} \mathrm{O}^{\mathrm{b}} \\
37^{\circ} \mathrm{C}, 2 \mathrm{~h}\end{array}$} & \multicolumn{2}{|c|}{$\mathrm{HCl} \mathrm{pH} 1.5,85^{\circ} \mathrm{C}$} & \multicolumn{2}{|c|}{$\mathrm{EDTA}^{\mathrm{c}} \mathrm{pH} 3.3,85^{\circ} \mathrm{C}$} & \multirow{2}{*}{$\begin{array}{c}\mathrm{AO}^{\mathrm{d}} \mathrm{pH} 3.3 \\
85^{\circ} \mathrm{C}, 4 \mathrm{~h}\end{array}$} & \multirow{2}{*}{$\begin{array}{c}\mathrm{SHP}^{\mathrm{e}} \mathrm{pH} 3.3 \\
85^{\circ} \mathrm{C}, 4 \mathrm{~h}\end{array}$} \\
\hline & & $1 \mathrm{~h}$ & $4 \mathrm{~h}$ & $1 \mathrm{~h}$ & $4 \mathrm{~h}$ & & \\
\hline Rhamnose & 0.84 & 2.16 & 2.93 & 1.13 & 0.62 & 0.99 & 1.38 \\
\hline Arabinose & 3.08 & 1.92 & 0.80 & 6.29 & 4.04 & 3.82 & 3.03 \\
\hline Mannose & 0.28 & 0.23 & 0.22 & 0.27 & 0.73 & 0.49 & 0.66 \\
\hline Glucose & 0.86 & 1.02 & 1.23 & 0.62 & 0.64 & 0.48 & 1.08 \\
\hline Galactose & 2.15 & 2.61 & 4.07 & 2.42 & 1.63 & 1.86 & 1.14 \\
\hline Total & 7.21 & 7.94 & 9.25 & 10.73 & 7.66 & 7.64 & 7.29 \\
\hline
\end{tabular}

${ }^{a}$ Data are expressed on a dry basis of pectin samples, and represent the mean of duplicate runs. ${ }^{\mathrm{b}}$ Indication of the pectin fraction solubilized during the proteolysis $\left(0.1 \mathrm{M}\right.$ sodium phosphate buffer, $\left.\mathrm{pH} 7.5,37^{\circ} \mathrm{C}, 2 \mathrm{~h}\right) .{ }^{\mathrm{c}}$ Abbreviation for ethylenediamine tetraacetate. ${ }^{\mathrm{d}} \mathrm{Abbreviation}$ for ammonium oxalate. ${ }^{\mathrm{e}}$ Abbreviation for sodium hexametaphosphate. ${ }^{\mathrm{f}} \mathrm{ND}=$ Not detected.

conditions used, such as extraction system, temperature, and time. The gelling capacity of pectin decreases with an increase in the degree of acetylation. ${ }^{22}$ The presence of acetyl groups on a relatively small molecule might prevent beet pectin from gelling. ${ }^{24}$ Partial acid hydrolysis of the acetyl groups restored the gelation power of the pectin. $^{1,25}$

Besides the presence of acetyl groups, another special feature of sugar beet pectins is that they contain ferulic acid and $p$-coumaric acid. The presence of such hydroxycinnamic acids has been reported in Monocotyledons, including Graminaceae such as wheat straw, ${ }^{26}$ oil palm trunks, ${ }^{27}$ and abaca fiber, ${ }^{28}$ and Chenopodiacees such as spinach and sugar beet. ${ }^{5,29}$ Our results showed that ferulic acid in pectin samples extracted by $\mathrm{HCl}(\mathrm{pH} 1.5$,

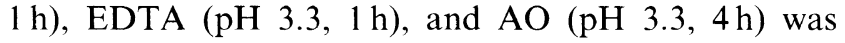
comparatively higher $(0.59 \%$ and $0.69 \%)$ than those isolated in other procedures. This content of ferulic acid in beet pectins was, in general, similar to the results obtained by Michel et al. ${ }^{23}$ and Phatak et al. ${ }^{1}$ After extraction of SBP with methanol for $16 \mathrm{~h}$, the extracted residue contained $1.2 \mathrm{mg}$ of hydroxycinnamic acids per gram of dry cell walls. The molar ratio of $p$-coumaric, ferulic, and diferulic acids, determined by HPLC, was $1: 165: 0.6^{30}$ A study on enzymic release of ferulic acid from SBP, Micard et al. ${ }^{29}$ reported that the SBP contained $0.79 \%$ ferulic acid. Further studies demonstrated that ferulic acid is linked to the pectic neutral side-chains and is found to be esterified to arabinose and galactose residues in SBP, with $50-55 \%$ of the feruloyl groups esterified to arabinose and $45-50 \%$ to galactose. ${ }^{8}$ Feruloyl groups are linked in position C-2 of L-arabinofuranose residues of the main core of $\alpha-(1 \rightarrow 5)$-linked arabinan chains and on C-6 of the D-galactopyranose residues of the main core of $\beta$ - $(1 \rightarrow 4)$-linked galactan chains. $^{3,4} 1$ out of 56 arabinose residues and 1 out of 16 galactose residues, present as pectic side-chains in SBP, carry a feruloyl group. ${ }^{8}$ These feruloylated side chains of arabinan and (arabino) galactan polysaccharides are thought to play an important role in connecting rhamnogalacturonan to other cell wall components. Furthermore, ferulic acid substituents can dimerize to form diferuloylated bridges between side chains, between different rhamnogalacturonan molecules and possibly between other feruloylated cell wall components such as arabinoxylans. ${ }^{5}$ This high amount of feruloyl groups is of especial interest, as it is possible to cross-link polysaccharides under oxidative conditions at the feruloyl groups, thus increasing the molecular weight and resulting in gelling of sugar beet pectins. ${ }^{2}$

The sugar composition of the pectins is given in Table II. In the current study the total neutral sugar content ranged from $7.21 \%$ to $10.73 \%$. Arabinose and galactose were the predominant sugars in all the pectin samples. Small amount of rhamnose, glucose, and mannose were also present. The results obtained were consistent with those of Rombouts and Thibault, ${ }^{5}$ Phatak et al. ${ }^{1}$ and Kobayashi et al. ${ }^{31}$ These authors also showed that sugar beet pectin consists of large smooth regions and small hairy regions, in which arabinose and galactose are located in the hairy fragment, while the rhamnose is involved in the pectic backbone and may constitute the point of attachment of the neutral sugar side chains. ${ }^{9,32}$ The higher content of arabinose than of galactose, with small amounts of rhamnose in EDTA, AO, SHP, and water extracted pectins, indicated that the neutral sugar (linkage-) compositions of these extracts were very similar, and also the presence of a rhamnogalacturonan with highly branched arabinonans and some galactose attached to it. This is in agreement with the results obtained from the studies of sugar beet pectin extracted with EDTA under alkaline conditions, ${ }^{2}$ but in contrast to acid $(\mathrm{HCl})$ extracted pectins, which contained galactose as main neutral sugar since most of the arabinose has been removed during the acid condition. Compared to the other extraction agents, a relatively higher amount of rhamnose $(2.16-2.93 \%)$ was found in the acid $(\mathrm{HCl})$ extracted pectins, indicating the present of more hairy regions. Further studies suggested that feruloyl groups are esterified to the arabinofuranosyl residues of the main core of $\alpha-(1 \rightarrow 5)$-linked arabinan chains, and to the galactopyranosyl residues of the main core of $\beta$ - $(1 \rightarrow 4)$-linked galactan chains in the hairy regions of sugar beet pectins. ${ }^{7}$

\section{Composition of Associated Lignin}

In addition to ferulic acid, the presence of other phenols in the isolated pectins was confirmed by alkaline nitrobenzene oxidation and HPLC analysis. The data are shown in Table III. Obviously, the predominant phenol 
Table III. The yield ( $\%$ sample, w/w) of phenolic acids and aldehydes from alkaline nitrobenzene oxidation of residual lignin in the pectin fractions extracted from sugar beet pulp

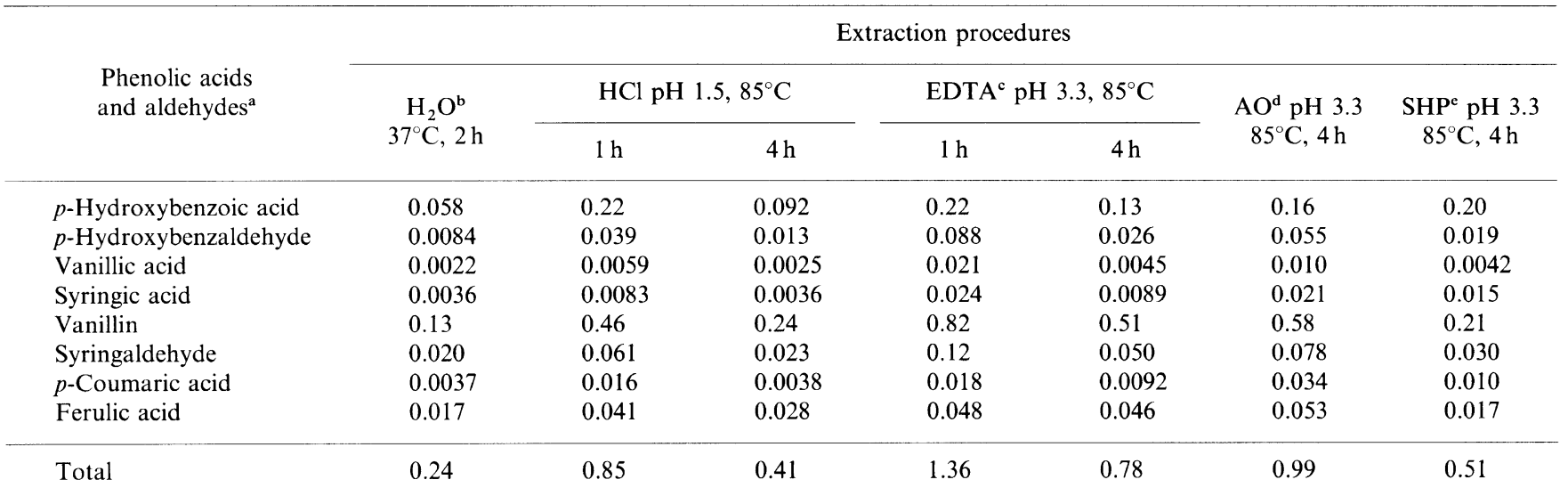

${ }^{a}$ Data are expressed on a dry basis of pectin samples, and represent the mean of duplicate runs. ${ }^{\mathrm{b}}$ Indication of the pectin fraction solublized during the proteolysis $\left(0.1 \mathrm{M}\right.$ sodium phosphate buffer, $\left.\mathrm{pH} 7.5,37^{\circ} \mathrm{C}, 2 \mathrm{~h}\right) . \quad{ }^{\mathrm{c}}$ Abbreviation for ethylenediamine tetraacetate. ${ }^{\mathrm{d}}$ Abbreviation for ammonium oxalate. ${ }^{\mathrm{e}}$ Abbreviation for sodium hexametaphosphate.

Table IV. The weight-average $\left(M_{w}\right)$, number-average $\left(M_{n}\right)$ molecular weights, and the polydispersity $\left(M_{w} / M_{n}\right)$ of pectin fractions extracted from sugar beet pulp

\begin{tabular}{|c|c|c|c|}
\hline $\begin{array}{l}\text { Pectin fractions/ } \\
\text { extraction procedures }\end{array}$ & $\bar{M}_{w}$ & $\bar{M}_{n}$ & $\bar{M}_{w} / \bar{M}_{n}$ \\
\hline $\mathrm{H}_{2} \mathrm{O}^{\mathrm{a}}$ pH $7.5,37^{\circ} \mathrm{C}, 2 \mathrm{~h}$ & 83100 & 8040 & 10.34 \\
\hline $\mathrm{HCl} \mathrm{pH} 1.5,85^{\circ} \mathrm{C}, 1 \mathrm{~h}$ & 58110 & 8210 & 7.08 \\
\hline $\mathrm{HCl} \mathrm{pH} 1.5,85^{\circ} \mathrm{C}, 4 \mathrm{~h}$ & 91440 & 7800 & 11.72 \\
\hline $\mathrm{EDTA}^{\mathrm{b}} \mathrm{pH} 3.3,85^{\circ} \mathrm{C}, 1 \mathrm{~h}$ & 54300 & 5400 & 10.06 \\
\hline EDTA pH $3.3,85^{\circ} \mathrm{C}, 4 \mathrm{~h}$ & 61420 & 5670 & 10.83 \\
\hline $\mathrm{AO}^{\mathrm{c}} \mathrm{pH} 3.3,85^{\circ} \mathrm{C}, 4 \mathrm{~h}$ & 77270 & 6390 & 12.09 \\
\hline $\mathrm{SHP}^{\mathrm{d}} \mathrm{pH} 3.3,8.5^{\circ} \mathrm{C}, 4 \mathrm{~h}$ & 59270 & 9920 & 5.97 \\
\hline
\end{tabular}

${ }^{\mathrm{a}}$ Indication of the pectin fraction solubilized during the proteolysis ( $0.1 \mathrm{M}$ sodium phosphate buffer, $\left.\mathrm{pH} 7.5,37^{\circ} \mathrm{C}, 2 \mathrm{~h}\right) .{ }^{\mathrm{b}}$ Abbreviation for ethylenediamine tetraacetate. ${ }^{\mathrm{c}}$ Abbreviation for ammonium oxalate. ${ }^{\mathrm{d}}$ Abbreviation for sodium hexametaphosphate.

was found to be vanillin, suggesting that the majority of the pectins are linked to lignin with guaiacyl units. A relatively high amount of $p$-hydroxybenzoic acid in the nitrobenzene oxidation products was partially due to the oxidation of associated $p$-coumaric acid. Other phenolic acids and aldehydes such as $p$-hydroxybenzaldehyde, vanillic acid, syringic acid, and syringaldehyde were also identified in all the mixtures produced by nitrobenzene oxidation. The higher yields of phenolic monomers in the pectins extracted by $\mathrm{HCl}$ and EDTA at $85^{\circ} \mathrm{C}$ for $1 \mathrm{~h}$ than those obtained by $\mathrm{HCl}$ and EDTA at $85^{\circ} \mathrm{C}$ for $4 \mathrm{~h}$ suggested that more ether bonds between lignin and the neutral sugars, or ester bonds between lignin and galacturonic acid, were cleaved during the acidic media extraction for $4 \mathrm{~h}$. The presence of these phenols, other than $p$-coumaric and ferulic acids, was also indicated by the colormetric measurement. However, these phenols were not recovered and identified in the studies of Guillon and Thibault. ${ }^{9}$ The current findings primarily indicate that lignin is tightly associated with pectin and hemicelluloses in SBP cell walls.

\section{Molecular Weight}

The weight-average $\left(M_{w}\right)$ and number-average $\left(M_{n}\right)$ molecular weights, and the polydispersity $\left(M_{w} / M_{n}\right)$ of the pectins are presented in Table IV. As can be seen, all the pectin fractions showed a high degree of polymerization with molecular-average weights between 54300 and $91440 \mathrm{Da}$. The values obtained in the current study are higher than those reported previously in literature for sugar beet pectins. ${ }^{1,5,21,23,33}$ All the authors reported that the viscosity-average molecular masses of SBP pectins are low, as compared to those pectins isolated from apple, citrus fruits, or cherries, which are in the order of 70000 and $90000 \mathrm{Da}$. For example, with the study of the relationship between extraction procedure of sugar beet pectin and intrinsic viscositymolecular weight, Arslan ${ }^{21}$ indicated that the molecular weight of pectins obtained by extraction with $\mathrm{HCl}, \mathrm{AO}$, and EDTA were 41300, 30400, and 15100, respectively. Increase of extraction time from 1 to $4 \mathrm{~h}$ during the $\mathrm{HCl}$ and EDTA extractions resulted in growth of molecularaverage weight from 58110 to 91440 and 54300 to $61420 \mathrm{Da}$, respectively. This observation indicated that extension of the extraction period favors the extraction of large molecules of pectins from sugar beet cell walls. However, due to the much lower molecular weight of pectin obtained by $\mathrm{HCl}$, Phatak et al. ${ }^{1}$ suggested that degradation might occur during the acid extraction. These different molecular weights of sugar beet pectins were probably due to the nature of the samples, and the variety of methods and different standards used.

The molecular-weight distribution pattern of the pectin isolated by $0.2 \% \mathrm{AO}$ at $\mathrm{pH} 3.3,85^{\circ} \mathrm{C}$ for $4 \mathrm{~h}$ is illustrated in Figure 4, which showed one significant peak and three small peaks. The molecular-weight distribution ranged between 2338000 and $1430 \mathrm{Da}$. The small peak I eluted in the void volume $(6.47 \mathrm{~mL})$ and had a molecular weight equal to $425570 \mathrm{Da}$. The major peak II had a molecular weight around $33040 \mathrm{Da}$. The low molecular weights eluted at peaks III and IV were probably due to the degradation products of pectin or the associated lignins.

\section{FT-IR Spectra}

The FT-IR spectra of $\mathrm{HCl}$ and EDTA isolated pectins are shown in Figure 5. The pectic substances belong to a class of carboxypolysaccharides, which differ from 


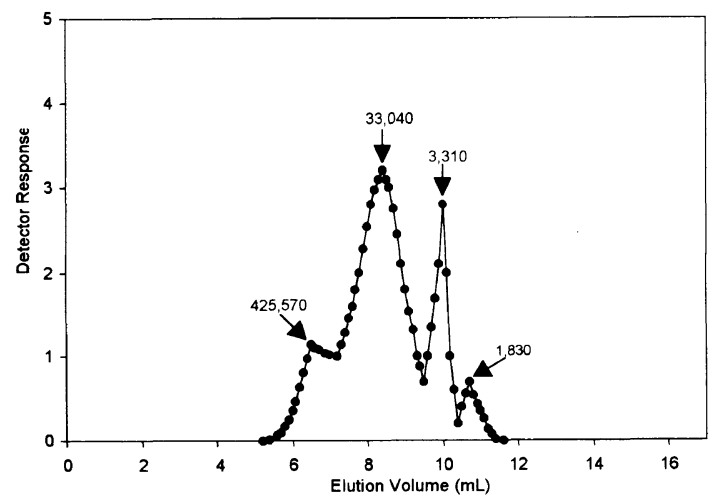

Figure 4. GPC molecular weight distribution of pectin extracted with $0.2 \%$ ammonium oxalate at $\mathrm{pH} 3.3$ and $85^{\circ} \mathrm{C}$ for $4 \mathrm{~h}$.

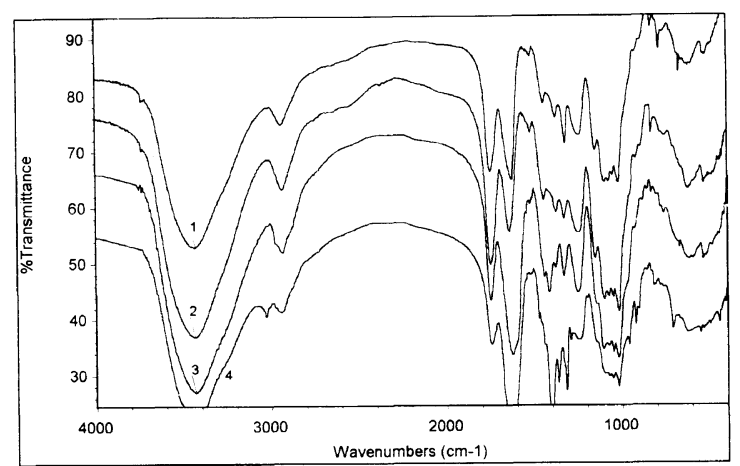

Figure 5. FT-IR spectra of $\mathrm{HCl}$ extracted pectins $\left(1, \mathrm{pH} 1.5,85^{\circ} \mathrm{C}\right.$, $1 \mathrm{~h}),\left(2, \mathrm{pH} 1.5,85^{\circ} \mathrm{C}, 4 \mathrm{~h}\right)$ and $0.2 \%$ EDTA extracted pectins $(3, \mathrm{pH}$ $\left.3.3,85^{\circ} \mathrm{C}, 1 \mathrm{~h}\right),\left(4, \mathrm{pH} 1.5,85^{\circ} \mathrm{C}, 4 \mathrm{~h}\right)$.

neutral polysaccharides, with an intense band in the region $1748 \mathrm{~cm}^{-1}$ (for salts $1639 \mathrm{~cm}^{-1}$ ) related to vibrations of the carboxyl group. ${ }^{34}$ From this point, it can be indicated that the $\mathrm{HCl}$ extracted pectins showed significant ester bands at $1748 \mathrm{~cm}^{-1}$, while the EDTA extracted pectins appeared in salt form as shown at $1639 \mathrm{~cm}^{-1}$, which corresponded with the ash content. The intensity ratio of the bands vas $\left(\mathrm{COO}^{-}\right)$at $1639 \mathrm{~cm}^{-1}$ and $v(\mathrm{C}=\mathrm{O})$ ester at $1748 \mathrm{~cm}^{-1}$ corresponds to fully deesterified pectin and Me pectate. ${ }^{35}$ As can be observed in Figure 5, The intensity of the band at $1748 \mathrm{~cm}^{-1}$ in the pectin spectra decreased in the following order: $\mathrm{HCl}(4 \mathrm{~h}), \mathrm{HCl}(1 \mathrm{~h}), \operatorname{EDTA}(1 \mathrm{~h}), \operatorname{EDTA}(4 \mathrm{~h})$, which, in general, corresponded with the order of methylation degree, which was $77.51 \%, 66.66 \%, 61.54 \%$, and $61.27 \%$, respectively. Structural features arising from particular conformations around the glycosidic bond of the pectins are observable in the $990-1100 \mathrm{~cm}^{-1}$ range. ${ }^{36}$ The prominent bands at 1016 and $1050 \mathrm{~cm}^{-1}$ are attributable to the $\mathrm{C}-\mathrm{O}$ stretching in $\mathrm{C}-\mathrm{O}-\mathrm{C}$ linkages and $\mathrm{C}-\mathrm{OH}$ bending. The bands at 1071, 1078, and 1098 $\mathrm{cm}^{-1}$ correspond to the ring vibration and $\mathrm{C}-\mathrm{OH}$ bending. ${ }^{37} \mathrm{~A}$ small band at $1516 \mathrm{~cm}^{-1}$ shows the aromatic skeletal vibrations for guaiacyl alcohol in associated lignin precursors.

The FT-IR spectra of the pectins solubilized in water during the proteolysis and isolated by AO (Figure 6) appeared similar to the pectin spectra extracted by $\mathrm{HCl}$ and EDTA shown in Figure 5, indicating the same quality of pectins. As mentioned earlier, a relatively stronger intensity at $1748 \mathrm{~cm}^{-1}$ in water solubilized pectin spec-

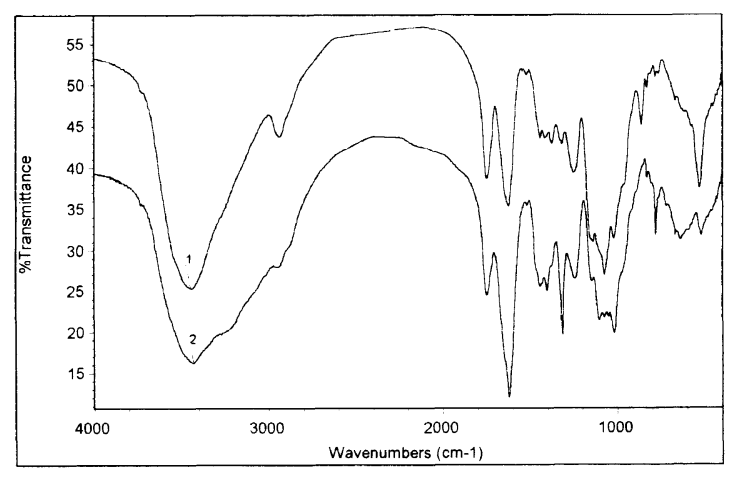

Figure 6. FT-IR spectra of water soluble pectin obtained during the proteolysis $\left(37^{\circ} \mathrm{C}, 2 \mathrm{~h}\right)(1)$ and $0.2 \% \mathrm{AO}\left(\mathrm{pH} 3.3,85^{\circ} \mathrm{C}, 4 \mathrm{~h}\right)$ extracted pectin (2).

Table V. The viscosity and optical rotation of isolated pectin fractions

\begin{tabular}{|c|c|c|}
\hline $\begin{array}{l}\text { Pectin fractions/ } \\
\text { extraction procedures }\end{array}$ & Viscosity/cps & $\begin{array}{l}\text { Optical rotation } \\
\qquad[\alpha]_{\mathrm{D}}^{20}\end{array}$ \\
\hline Citrus Pectin & 113.80 & +182.60 \\
\hline $\mathrm{H}_{2} \mathrm{O}^{\mathrm{a}} \mathrm{pH} 7.5,37^{\circ} \mathrm{C}, 2 \mathrm{~h}$ & 3.36 & +136.80 \\
\hline $\mathrm{HCl} \mathrm{pH} 1.5,85^{\circ} \mathrm{C}, 1 \mathrm{~h}$ & 2.94 & +182.10 \\
\hline $\mathrm{HCl} \mathrm{pH} 1.5,85^{\circ} \mathrm{C}, 4 \mathrm{~h}$ & 3.06 & +148.40 \\
\hline EDTA $^{\mathrm{b}} \mathrm{pH} 3.3,85^{\circ} \mathrm{C}, 1 \mathrm{~h}$ & 3.38 & +95.60 \\
\hline EDTA pH $3.3,85^{\circ} \mathrm{C}, 4 \mathrm{~h}$ & 3.43 & +107.00 \\
\hline $\mathrm{AO}^{\mathrm{c}} \mathrm{pH} 3.3,85^{\circ} \mathrm{C}, 4 \mathrm{~h}$ & 2.78 & +143.60 \\
\hline $\mathrm{SHP}^{\mathrm{d}} \mathrm{pH} 3.3,85^{\circ} \mathrm{C}, 4 \mathrm{~h}$ & 2.54 & +117.40 \\
\hline
\end{tabular}

${ }^{a}$ Indication of the pectin fraction solubilized during the proteolysis $\left(0.1 \mathrm{M}\right.$ sodium phosphate buffer, $\left.\mathrm{pH} 7.5,37^{\circ} \mathrm{C}, 2 \mathrm{~h}\right) .{ }^{\mathrm{b}}$ Abbreviation for ethylenediamine tetraacetate. ${ }^{\mathrm{c}}$ Abbreviation for ammonium oxalate. ${ }^{\mathrm{d}}$ Abbreviation for sodium hexametaphosphate.

trum than that of pectin isolated by AO suggested a slightly higher methylation degree $(80.42 \%$, Table I) of water solubilized pectin than of AO extracted pectin (78.89\%, Table I). Furthermore, the spectrum of water solubilized pectin showed higher intensities at bands 1071 and $860 \mathrm{~cm}^{-1}$, while the pectin isolated by $\mathrm{AO}$ showed higher intensities at bands 1331 and $1016 \mathrm{~cm}^{-1}$. A very small band at $1518 \mathrm{~cm}^{-1}$ in both of the pectin spectra indicates the presence of a small amount of associated lignin in extracted pectins.

\section{Viscosity, Optical Rotation, and Gelation}

The viscosity and optical rotation of the isolated sugar beet pectins are given in Table $\mathrm{V}$. The values of the viscosity, ranged between 2.54 and $3.43 \mathrm{cps}$, were much lower than that observed in citrus pectin $(113.80 \mathrm{cps})$. Optical rotation of the pectins varied from 95.60 to 182.10. Water solubilized pectin, and $\mathrm{HCl}$ and $\mathrm{AO}$ isolated pectins showed higher degrees of optical rotation than the pectins extracted by EDTA and SHP. There was no gel formation observed at $1.0 \%$ concentration in any of the pectin samples. This poor gelling ability of the sugar beet pectins was partially attributed to the presence of acetyl groups, ${ }^{22}$ and to their relatively low molecular weight. However, improvement of the gelling power can be achieved by amidation which would decrease both their acetyl and methyl contents and also make the pectins calcium-sensitive. Another way of improving gel formation would be by cross-linking feruloyl groups under peroxidase and 
hydrogen peroxide conditions. ${ }^{23}$

\section{SUMMARY}

Based on the maximum yield of galacturonic acid and minimum ash content of sugar beet pectin, the optimum extraction procedure for isolation of pectin from SBP was found to be $\mathrm{HCl}$ extraction at $\mathrm{pH} 1.5,85^{\circ} \mathrm{C}$ for $4 \mathrm{~h}$, in which the pectin contained $84.61 \%$ anhydrogalacturonic acid and $2.69 \%$ ash. The pectin samples both solubilized in water during the proteolysis and extracted by $\mathrm{HCl}$, EDTA, AO, and SHP, do not show much difference in their physico-chemical properties. Their molecular-average weights ranged between 59270 and $91440 \mathrm{Da}$. All of the isolated pectins are high methoxy pectins $(61.54-80.42 \%)$ and contained acetyl groups $(2.00-2.74 \%)$. They had low viscosity and did not gel under high sucrose conditions. The neutral sugar contents in isolated pectins varied from $7.21 \%$ to $10.73 \%$ and arabinose and galactose were the predominant sugar constituents. In addition to the esterified ferulic acid in extracted pectins, the current findings indicated that the lignin, mainly guaiacyl alcohol, is tightly associated with pectin in SBP cell walls.

Acknowledgments. The authors are grateful for the financial support of this research from the Danisco Sugar Development Centre, Denmark, for the 'Potential Utilization of Sugar Beet Pulp in Non-Food Areas' project, and also to Dr. James Bolton, Director of the BioComposites Centre, for the award of a research fellowship to R.-C. Sun.

\section{REFERENCES}

1. L. Phatak, K. C. Chang, and G. Brown, J. Food Sci., 53, 830 (1988).

2. A. Oosterveld, G. Beldman, H. A. Schols, and A. G. J. Voragen, Carbohydr. Res., 288, 143 (1996).

3. V. Micard, C. M. G. C. Renard, and J.-F. Thibault, Enzyme and Microbial Technology, 19, 162 (1996).

4. P. A. Kroon and G. Williamson, Biotechnol. Appl. Biochem., 23, 263 (1996).

5. F. M. Rombouts and J.-F. Thibault, Carbohydr. Res., 154, 177 (1986).
6. F. Guillon and J. F. Thibault, Carbohydr. Res, 190, 85 (1989).

7. I. Colquhoun, M.-C. Ralt, J.-F. Thibault, C. B. Faulds, and G. Williamson, Carbohydr. Res., 263, 243 (1994).

8. M.-C. Ralet, J.-F. Thibault, C. B. Faulds, and G. Williamson, Carbohydr. Res., 263, 227 (1994).

9. F. Guillon and J. F. Thibault, Lebensm. Wiss. u.-Technol., 21, 198 (1988).

10. A. B. Blakeney, P. J. Harris, R. J. Henry, and B. A. Stone, Carbohydr. Res., 113, 291 (1983).

11. N. Blumenkrantz and G. Asboe-Hansen, Anal, Biochem., 54, 484 (1973).

12. C. Wedig, E. H. Jaster, and K. J. Moore, J. Agric. Food Chem., 35, 214 (1987)

13. D. J. Wood and I. R. Siddiqui, Anal. Biochem., 39, 418 (1971).

14. B. L. Browning, in "Methods of Wood Chemistry," Academic Press, New Yord, N.Y., 1967, p 629.

15. S. A. Andon, Food Technol., 41, 74 (1987).

16. R. M. McCready, A. D. Shepherd, H. A. Swenson, R. F. Erlandsen, and W. D. Maclay, Anal. Chem., 23, 975 (1951).

17. K. C. Chang and A. Miyamoto, J. Food Sci., 57, 1435 (1992).

18. J. M. Lawther, R.-C. Sun, and W. B. Banks, J. Agric. Food Chem., 43, 667 (1995)

19. R. C. Sun, J. M. Lawther, and W. B. Banks, Industrial Crops and Products, 4, 127 (1995)

20. R. C. Sun, J. M. Lawther, and W. B. Banks, Carbohydr. Polym., 29, 325 (1996).

21. N. Arslan, J. Food Sci. Technol., 32, 381 (1995)

22. R. M. McCready, J. Am. Soc. Sugar Beet Technol., 14, 260 (1966).

23. F. Michel, J.-F. Thibault, C. Mercier, F. Heitz, and F. Pouillaude, J. Food Sci., 50, 1499 (1985).

24. E. Roboz and A. Van Hook, Proc. Am. Soc. Sugar Beet Technol., 4, 574 (1946).

25. E. L. Pippen, R. M. McCready, and H. S. Owens., J. Am. Chem. Soc., 72, 813 (1950).

26. R. C. Sun, J. M. Lawther, and W. B. Banks, Industrial Crops and Products, 6, 1 (1997a).

27. R. C. Sun, L. Mott, and J. Bolton, J. Agric. Food Chem., in press.

28. R. C. Sun, A. Goodwin, and J. M. Lawther, to be published.

29. V. Micard, C. M. G. C. Renard, and J.-F. Thibault, Lebensm. Wiss. u.-Technol., 27, 59 (1994).

30. T. Ishii, Plant Cell Physiol., 35, 701 (1994).

31. M. Kobayashi, K. Funane, H. Ueyama, S. Ohya, M. Tanaka, and Y. Kato, Biosci. Biotechnol. Biochem., 57, 998 (1993).

32. R. R. Selvendran, J. Cell Sci., Supplement, 2, 51 (1985).

33. C. C. H. Wang and K. C. Chang, J. Food Sci., 59, 1153 (1994).

34. M. P. Filippov, Food Hydrocolloids, 6, 115 (1992).

35. M. P. Filippov, G. A. Shkolenko, and R. Kohn, Chem. Zvesti., 32, 218 (1978).

36. M. Kacurakova and M. Mathlouthi, Carbohydr. Res., 284, 145 (1996).

37. M. Kacurakova, A. Ebringerova, J. Hirsch, and Z. Hromadkova, J. Sci. Food Agric., 66, 423 (1994). 